\title{
Language Mixing as a Persuasive Strategy in Oxford, MS Bodley 649
}

\author{
Helena Halmari*
}

One of the salient features of Oxford, MS Bodley 649, a fifteenth-century sermon collection, is its frequent switching from Latin to English - and back to Latin again. Building on Wenzel's (1994) groundbreaking work on macaronic sermons, I discuss the rhetorical characteristics of English elements in MS Bodley 649, with the purpose of showing that language mixing in this collection is not random but rather one of the rhetorical devices that the author uses for persuasion. The English elements are frequently used to build grammatical cohesion through structural parallelism. Also, lexical and semantic cohesion are achieved via repetition of the same words in both languages or through English paraphrases of Latin scriptural content. Alliteration, another rhetorical device, often coincides with language switches within the sermons. I hope to show that, together with other rhetorical strategies, mixing English into Latin constitutes one means within an entire bundle of linguistic devices that all contribute to the persuasive purpose of the genre. As a preliminary finding of some work in progress, I report on the nature of the English words mixed into these highly scholastic and often allegorical sermons. The English elements within the sermons tend to provide content that is mundane, or objectionable (from the point of view of Christian conduct and goals), or even merely negative (if not repulsive). An important conclusion is that none of the rhetorical strategies that overlap with code-switching into English are used mechanically and systematically by the sermonist; the coincidence of the bundled persuasive features is never predictable. However, this does not mean that mixing English elements into Latin in MS Bodley 649 should be characterized as random. A persuasive sermon is not tamely predictable in its delivery; it must offer surprises as audience-engagement strategies. The most salient surprises in MS Bodley 649 are provided by the English elements.

Keywords: macaronic sermons; Oxford MS Bodley 649; code-switching, persuasion, cohesive devices; alliteration; repetition; structural parallelism

\section{Introduction}

Oxford, MS Bodley 649 is an early fifteenth-century sermon collection, famous for its intensively macaronic structure. In MS Bodley 649, the predominantly Latin sermons incorporate words, phrases, and clauses from English, in a pattern that seems enigmatic. This MS is a typical representative of the macaronic genre. One of the earliest definitions of the adjective macaronic found is from 1611, listed in the Oxford English Dictionary with the following entry:

\footnotetext{
* Correspondence details: Helena Halmari, Sam Houston State University, Department of English, P.O. Box 2146, 1901 University Ave., Huntsville, Texas. Email: halmari@shsu.edu.
} 
(1) 1611 R. Cotgrave Dict. French \& Eng. Tongues Macaronique, a Macaronick; a confused heape, or huddle of many seuerall things.

The other listed historical meanings for macaronic in the Oxford English Dictionary are derogatory or pejorative. The American Heritage Dictionary of the English Language, 1992, 3rd edition, gives the following two meanings for macaronic:

(2) 1. Of or containing a mixture of vernacular words with Latin words or with vernacular words given Latinate endings: macaronic verse. 2. Of or involving a mixture of two or more languages. [New Latin macaronicus, from Italian dialectal maccarone, dumpling, macaroni (perhaps from the way macaroni is heaped on a plate and mixed with sauce).

While the American Heritage Dictionary's meanings 1 and 2 do not involve a value judgment, the parenthetical explanation referencing sauce on a heaped pile of macaroni does not connote an elevated genre like sermons. These dictionary entries seem more a reflection of their writers' tastes than of the quality of the macaronic sermons themselves that they came to designate, barring these sermons from serious scholarly inquiry for many decades, if not for centuries. ${ }^{1}$

Siegfried Wenzel, who dedicated a good part of his academic career to the study of macaronic sermons, defines the term macaronic thus:

(3) [T]he term macaronic has been adopted by modern English writers and is being applied to any kind of verse that mixes English and Latin (or French) in different structural forms and for a variety of rhetorical purposes. [...] Such macaronic texts can be found not only in verse but [also] in prose. There is probably no religious or devotional text in Middle English prose that does not include some Latin words, phrases, or sentences. ${ }^{2}$

Oxford, MS Bodley 649 is a collection of sermons, of which twenty-three show "a highly unique macaronic mixture of Latin and English «. ${ }^{3}$ Latin is the base language, with English (and sometimes French) pouring in as the sauce, or getting tangled with the strings of pasta. Wenzel's definition of macaronic, unlike many dictionary definitions and references to medieval macaronic texts, does not have any pejorative connotations. The genre of sermons in medieval times, just as today, is, in fact, a "high « genre, to evoke Ferguson's 1959 notion of diglossia. ${ }^{4}$ But Ferguson's high vs. low codes involve a clear situational separation of the two language varieties: the low variety, for instance, in the marketplace, and the high variety in places of worship or the halls of academia. In macaronic sermons this principle does not work: the sermonist brings both Latin (the "high" variety and the expected tongue) and the vernacular (the unexpected "low" variety) into the same physical space, at the same time, delivered simultaneously by the same speaker to the same audience.

See Wenzel, Macaronic Sermons, v. For an overview of the negative attitudes toward mixed languages in historical texts, see Schendl and Wright, Code-switching in early English, 16-18. 
Scholars have wondered why Bodley 649 would mix so much of the "low « English into its "high « Latin. Is this simply a reflection of England post Statute of Pleading in $1362^{5}$ and "English triumphant " ${ }^{6}$ where these bilingual sermons showcase a microcosm of late-medieval England, literally pushing forward the vernacular on the battleground defined by the clause and the sentence? To an extent, the answer must be "yes «: by the fifteenth century, the road had been paved for English to take over from French in high society and from Latin in church. English had already suppressed and absorbed Scandinavian as another vernacular, and now the country was getting ready for the Reformation and the linguistic reconquest by English. A few centuries earlier, a clerical audience ${ }^{7}$ would most certainly have been preached to in monolingual Latin. However, those working on bilingualism in Medieval England ${ }^{8}$ and on language contact today, ${ }^{9}$ are not really surprised.

Example (4) comes from Horner's edition and translation. ${ }^{10}$ This example appears at the closing of Sermo 5, which is among the sermons typical in its bilingual structure. As in all the examples in this article, for clarity, Latin is in normal font (even when italicized in Horner); English is in italics, and Horner's translation follows:

(4) From Sermo 5, Oxford, Bodleian Library, MS Bodley 649, as edited and translated by Horner:

Set ex quo sicut predixi poru myzt and vertu angeli celestes pascuntur so daynteliche, terrestres homines sanati ita graciuslich, et demones inferni victi ita potenter, »in nomine Iesu omne genu flectatur celestium terrestrium et infernorum, « Ad Philippenses 2, »Fal eueri creature on kne in nomine Iesu celi, terre, et inferni." Et infernorum falle euery fende on kne and drede pe almyzti prince Iesu, quia sue armatura lucis erant victi, sicut dixi primo principali; terrestrium fal eueri mon on kne and lowe be al witti leche Iesu, quia sui surrippo sanguinis nos sanauit, sicut dixi in secundo; celestium falle euery angel on kne and worschip pe algodli lord Iesu, quia sue dulcedine deitatis pascuntur, sicut dixi in tercio. pus to loue and drede pis worthi Lorde and in his loue sic ducere nostram vitam mortalem quod post hanc pasci possimus with his daynte deitate in gloria, Iesus vobis concedat et michi qui pro nostra salute suum sanguinem effudit in cruce. Qui cum Patre, etc.

5 Rothwell, English and French.

6 Millward and Hayes, Biography, 147-148.

7 Wenzel, Macaronic Sermons, 71.

8 See, e.g., Schendl and Wright, Code-Switching; Pahta et al., Multilingual Practices; Classen, Multilingualism; Jefferson and Putter, Multilingualism in Medieval Britain; Trotter, Multilingualism.

9 To mention a few, see Thomason and Kaufman, Language Contact; Matras, Language Contact; Schreier and Hundt, Contact Language.

10 Horner, Macaronic Sermon Collection, 152-153. 
"But since as I said before through might and virtue the heavenly angels are fed so deliciously, earthly men are healed so graciously, and demons of hell conquered so powerfully, rat the name of Jesus every knee should bend in heaven, on earth, and under the earth, Philippians 3 [sic], , Let every creature in heaven, earth, and hell fall on knee at the name of Jesus.` And fall every fiend of hell on knee and dread the almighty prince Jesus, for by his armor of light they were conquered, as I said in the first principal; fall every man on earth on knee and love the all-wise leech Jesus, for by the syrup of his blood he healed us, as I said in the second; fall every angel in heaven on knee and worship the all-good lord Jesus, for by his sweetness of godhead they are fed, as I said in the third. So, may Jesus grant to you and to me to love and dread this worthy Lord and in his love thus to lead our mortal life so that after this we can be fed with his delicious godhead in glory, he who for our salvation poured out his blood on the cross. Who with the Father, etc.«

This passage is characteristic of the sermons in Bodley 649 except that, for the sake of illustrating a variety of English elements within a relatively short text, the concentration of English words is higher than the average in Bodley 649, as well as in Wenzel's bilingual sermon corpus of approximately 225,000 words; in the latter, the percentage of English words is 11.4 percent. ${ }^{11}$ The above passage consists of 163 words, out of which 97 are in Latin, 58 in English, and eight expressions - Iesu (5), Iesus (1), the numeral 2, and the abbreviation etc. - can be considered language-neutral. ${ }^{12}$ Table 1 shows the distribution of English vs. Latin words in this short passage:

Table 1. The distribution of Latin and English words in the sample passage from Sermo 5 $(\mathrm{n}=155)$.

$\begin{array}{ll}\text { Latin words } & 97(63 \%) \\ \text { English words } & 58(37 \%)\end{array}$

The passage above includes nine switches into English, listed in Table 2, together with their syntactic forms and, if phrases, their function within the sentence:

11 The numbers of Wenzel's corpus come from his statistical table of 43 macaronic sermons (Wenzel, Macaronic Sermons, 347-348). The Bodley 649 sermons form part of these data.

12 For the development of machine-identification of Latin vs. English and automated tagging of lexical categories, with Bodley 649 as a sample text, see Schultz and Keller, Code-switching ubique est. For examples of accessible medieval multilingual texts where language identification and editorial tagging has been completed, see, e.g., Piers Plowman Electronic Archive at piers.chass.ncsu.edu. 
Table 2. Examples of switched syntactic forms and their functions.

poru myzt and vertu

so daynteliche

graciuslich

"Fal eueri creature on kne ...»

falle euery fende on kne and drede be almyzti prince Iesu

fal eueri mon on kne and lowe pe al witti leche Iesu

falle euery angel on kne and worschip pe algodli lord Iesu

pus to loue and drede pis worthi Lorde and in his loue

with his daynte
PP/Adjunct

ADVP/Adjunct

ADVP/Adjunct

Clause

Clause (Coordinate)

Clause (Coordinate)

Clause (Coordinate)

Infinitive VP/Direct Object

Part of a PP/Adjunct

The English elements include one prepositional phrase (PP) and one first part of a PP; two adverbial phrases (ADVPs); four clauses (subjunctives); and an infinitive verb phrase (VP). In earlier work, we have shown that adjuncts (referred to as adverbials in traditional grammar) are easily switchable elements, as they belong to the periphery of the sentential syntax. ${ }^{13}$ The same explains the prevalence of four switched clausal elements in this tiny sample; clause boundaries are typical switching sites as they, obviously, are outside the grammatical constraints for switching. The one infinitival VP that functions as a direct object is left-dislocated. The switches in this passage thus consist of word-, phrase-, and clause-level elements. It seems that syntactic structure has a role to play in where English insertions appear. ${ }^{14}$ However, this chapter is not about structural forms; it is about Wenzel's second italicized phrase in the excerpt in (3) above: the "variety of rhetorical purposes « ${ }^{15} \mathrm{I}$ argue that while mixing is not random in terms of its syntactic structure, it is not completely random in its rhetorical purposes either. Naturally, mixing can never be predicted - neither do we know in advance when a preacher or a politician today will shift to a colloquial expression or to another dialect, but, post facto, we can often see that this style-shifting took place for a rhetorical, persuasive purpose.

14 There have been in-depth discussions of the "different structural forms (see example 3 above) of the language mixing in Bodley 649, by Wenzel (Macaronic Sermons) himself, but also by others, e.g., Schendl, Late medieval macaronic sermons; Schendl, Syntactic constraints, 67-86; Archan, Functional and Structural Aspects; Keller, Code-switched adjectives; Halmari and Regetz, Syntactic aspects.

15 Wenzel, Macaronic Sermons, 5. 


\section{The Rhetorical Aspects of Switching to English in Bodley 649}

With this article, my purpose is to make a small contribution to the work done by scholars like Owst, ${ }^{16}$ Haines, ${ }^{17}$ Machan, ${ }^{18}$ Johnson, ${ }^{19}$ and many others, in discussing the "variety of rhetorical purposes « for mixing Middle English into these predominantly Latin sermons. My goal, thus, is to look not at how but why. We know that this is a reflection of bilingualism in medieval England and, more generally, multilingual medieval Europe ${ }^{20}$ but why does the mixing happen? Wenzel lists a number of potential motives for what he refers to as the "macaronic texture ${ }^{21}$ He discusses - and quickly dismisses - a number of possible »reasons « for switching from Latin to English. Among these Wenzel lists and gives examples of coordination (5a), the desire to use the sermon author's favorite word, which happens to be an English word (5b), his favorite phrases, almost like his idiolectal mannerisms (5c); alliteration (5d); structural parallelism (5e); or, the use of English proverbial material (5f):

(5) Examples from Wenzel 1994:
(a) Gracia and comfort ${ }^{22}$
(b) ouerseile, wawe, stormis ${ }^{23}$
(c) be $\mathrm{x}$ never so $\mathrm{y}^{24}$
(d) lati rami, articuli, fadoun fast; made of marbilstonys; sua humilitas of herte ${ }^{25}$
(e) pus ignis caritatis extinguitur, pus humor deuocionis arescit, pus tota spiritualis vita subtrahit se [...]. ${ }^{26}$
(f) Si habes conscienciam to trede on a crossid stramen ${ }^{27}$

In (5a), the switch happens within a coordinated NP, where the English coordinator and matches in language with the second noun comfort. The words in example (5b) come from within one semantic field, that of seafaring, the metaphorical topic of the sermon. The fixed structural formula in (5c) is prevalent in the sermons of Bodley 649. Alliteration (5d) has been pointed out as a common feature of bilingual sermons, but it is, of course, a strong stylistic feature of Old English poetry, as well as a part of the alliterative revival during the Middle English period. ${ }^{28}$ In the last example in (5d), sua humilitas of herte, alliteration seems

See, e.g., Taavitsainen et al., Placing Middle English; Classen, Multilingualism; Schendl and Wright, Code-Switching; id., Code-switching in early English; Jefferson and Putter, Multilingualism in Medieval Britain; and Pahta et al., Multilingual Practices, to mention some recent collections on multilingualism in the Middle Ages.

21 Wenzel, Macaronic Sermons, 81.

22 Wenzel, Macaronic Sermons, 86.

23 Wenzel, Macaronic Sermons, 87.

24 Wenzel, Macaronic Sermons, 88.

25 Wenzel, Macaronic Sermons, 88-89.

26 Wenzel, Macaronic Sermons, 90.

27 Wenzel, Macaronic Sermons, 93.

28 See Turville-Petre, Alliterative Revival; also, Burrow and Duggan, Medieval Alliterative Poetry. For an analysis of alliteration in Bodley 649, see Halmari and Regetz, Language switching and alliteration. 
to function as a tie between the Latin humilitas and the English herte. Example (5e) shows a thrice-repeated English adverb pus, followed by a Latin NP-V combination: ignis caritatis extinguitur, humor deuocionis arescit, and tota spiritualis vita subtrahit se. Example (5f) contains English proverbial material: evidently, stepping over two crossed straws was considered bad luck. ${ }^{29}$

All the possible explanations and rationalizations for the macaronic structure, listed by Wenzel, were, in fact, dismissed almost immediately by Wenzel himself. The six patterns listed in (5) above are not used consistently, and very often there is no switching to English for these reasons. Therefore, is there any sense in attempting to explain what is going on in Bodley 649 - and, significantly, in the mind of its author, hypothesized to have been John Paunteley from Oxford ${ }^{30}$ In a sense, we are left wondering whether it is even possible to talk about the purpose of English in these bilingual sermons. Yet, in this article, I hope to show that the list of typical code-switching strategies in (5) above coincides significantly with elements in Halliday and Hasan's list of cohesion-building devices: referencing, substitution, conjunction, and grammatical and lexical cohesion. ${ }^{31}$ At first it seems oxymoronic to claim that, by breaking the linguistic cohesion within a sermon, a paragraph, and even a sentence through changing from Latin to English, the preacher is actually building coherence by the way he carries out these shifts.

\section{The Bundling of Rhetorical Features in Oxford, MS Bodley 649}

Because the macaronic sermons in Bodley 649 follow closely the Ars Praedicandi, the structural and rhetorical principles of effective, persuasive preaching, how does the mixing of Latin and English fit into the sermon's hortative goals? And what does this mixing do to the structure of the sermon? What good, if anything, does this macaronic texture achieve? Would it not hinder the sermonist from his persuasive goals? Or, does this macaronic texture actually reveal something about the sermonist's strategy in order to reach his persuasive goals?

In this article, I start from the premise that switching to English in Bodley 649 does not have (and does not need to have) an all-encompassing explanation, as switching to English is merely one of several effective rhetorical devices that the sermon author uses to reach out to, touch, and move his bilingual audience. Examples ( $5 \mathrm{a}-\mathrm{f}$ ) show what any good speaker does in an orally delivered message. Switching may be one salient method used, but switches also exhibit a number of other rhetorical strategies, often bundling these rhetorical devices. These often include rhyming in English.

29 Wenzel, Macaronic Sermons, 92.

30 Horner, Macaronic Sermon Collection, 6.

31 Halliday and Hasan, Cohesion in English. 
How, then, are the switches into English marked? Most often, there is no explicit signal when a transition from Latin to English - and back to Latin - takes place. In the manuscript, all text is in black, in the same hand, with no indication about the frequent language changes. This is in contrast to many other medieval religious manuscripts (for instance Piers Plowman), where rubrication shows language change. ${ }^{32}$ The means of these overt signals for a shift in language include red ink, boxing, bolding, boxing in red, and shifts in the size of the text. ${ }^{33}$

\section{Flagging, Repeating, Rhyming, Code-switching}

Even though very few of the switches are flagged in any way, one of the common means of explicitly introducing the switch is the following, from the beginning of Sermo 6, O-06 in Wenzel's system:

(6) Fortis armatus custodit atrium, Luce $\mathrm{XI}^{\circ}$. Anglice, A myzti werrour and a wyzt Kepes his halle armed brizt. Lego, $2^{\circ}$ Machabeorum XI [...]

"The strong man, fully armed, guards his courtyard, Luke 11. In English, A mighty warrior and wight Keeps his hall armed bright. I read in 2 Maccabees $11[\ldots] \ll^{34}$

Anglice appears a number of times in Bodley 649 as an overt and explicit flag for a switch. ${ }^{35}$ But example (6) is also in the form of a little rhyming jingle, a poem of sorts. A switch to English is not the sole rhetorical device here. The sermonist also switches to another genre: from the prose style of the sermon to reciting poetry. Example (7) provides another instance of using anglice as an explicit marker of transitioning into English, and he also uses the Latin vel sic "or thus" to signal the second reiteration, in English, of his original Latin content. However, the preacher also paraphrases the Latin content and its English translation in the form of a rhyming couplet. He thus ends up expressing the same content in three different ways: Latin prose, English prose, and English verse:

(7) Assumpsit eum in ciuitatem, vbi prius. Anglice: He toke him into the cite, vel sic:

He so mercy doth for Goddis sake, Into pe cite of mercy he schal be take.

Tutissima ciuitas in terris [...]

32 Robert Adams (pers. comm., April 2019) points out that the reason for these differences between the Bodley 649 and Piers Plowman manuscripts is obvious: Piers Plowman manuscripts were meant to be read; these sermons were merely meant to be heard.

33 For the role of visually marking language shifts in manuscripts, see Carroll et al., Pragmatics on the page; Benson, Another fine manuscript mess, 27; Halmari, Visual presentation of Latin.

34 Horner, Macaronic Sermon Collection, 154-155.

35 Langland does this too, signaling with anglice before he translates a Latin tag into English (Robert Adams, pers. comm., April 2019). 
"He took him into the city, as above. In English: He took him into the city, or thus, He so does mercy for God's sake,

Into the city of mercy he shall be take.

The safest city on earth $[. ..] \ll^{36}$

In addition to anglice or vel sic, isto modo "in this way« is another flag that the sermon writer uses to introduce the switch explicitly. In addition to the explicitly flagged switch of language, example (8) also illustrates a generic shift to verse:

(8) In iuuentutis mane, pulsat per sue passionis beneficium isto modo, , For pe I wax al rody opon pe rode, Mi blod y scheedde to wasche in pi hert; Amende be be [f. 6] tymes and seese of pi synne, Vndo pe dore of pin hert and let me inne.r In tue adolescencie meridie [...]

"In the morning of youth, he knocks through the benefit of his passion in this way, For thee I waxed all ruddy upon the rood, My blood I shed to wash thy heart; Amend thee soon and cease of thy sin, Undo the door of thy heart and let me in. In the noontime of your adulthood [...] « ${ }^{37}$

The four English verse lines in example (8) provide a colorful, stylistically vivid insertion. Here, the sermonist uses code-switching to quote, ${ }^{38}$ and the speech he is reporting comes from no lesser authority than Jesus himself. The importance of the content is marked by a switch of language to the vernacular and the shift of the genre to verse. In addition, the content is flagged by isto modo.

If anything, these explicitly marked switches, especially those flagged by anglice, provide concrete verification that the preacher was completely aware of preaching a bilingual sermon. It was his intention to use English; it was not an accident.

Example (9) is not a flagged switch, but it is another example of a language switch overlapping with a generic switch - again from the sermon prose to verse:

(9) >Cecidit corona capitis nostri; ve nobis quia peccauimus.

se garlond of blis is falle vs fro;

Alas for synne we haue al pis wo.r

Attendite de ista vindicta [...]

36 Horner, Macaronic Sermon Collection, 54-55.

37 Horner, Macaronic Sermon Collection, 44-45.

38 Code-switching often coincides with reported speech and quotations; see, for instance, McClure and McClure, Macro- and micro-sociolinguistic dimensions. McClure and McClure report this to be »by far the most frequent motivation for conversational code-switching« (p. 35). 
"'The crown fell from our head; woe to us for we have sinned.

The garland of bliss is fallen from us;

alas for sin we have all this woe.r

Pay heed to this vengeance $[. ..] \ll^{39}$

Here, too, the preacher is bundling three rhetorical strategies: repetition (paraphrasing the Latin in the vernacular); doing this in the form of rhyming verse; and shifting the language into English. The preacher's Latin does not rhyme; his English does.

At first, it seems that a shift from one genre (prose) to another (verse) would break the cohesion (and thus ultimately the coherence) within the sermon. However, repetition itself is a cohesion-building device: ${ }^{40}$ when the semantic content of the key message of the sermon is repeated in two different languages, what may at first look like a threat to the sermon's coherence actually functions to enforce it through semantic cohesion - albeit with lexical elements from two different languages.

\section{Building Cohesion through Repetition and Simultaneous Variation}

In examples (6-9) above, the preacher is making the switch of language highly salient by transitioning to English not only intersententially, between sentences, but also switching to a different genre - verse. Another, and much less noticeable, strategy of switching by the sermonist is introduced when he inserts English elements within the sentence, intrasententially. In Sermo 1, where the theme is "Now is the day of salvation", the sermon author refers to the urgency of repenting by repeatedly using the noun clock, both in Latin and in English. Example (10) shows the alteration between horologium and clok/clock:

(10) horologio - horologium - horologium - horologii - horologii -

horologio - horologium - pi clok most be set - set pi clok perafter -

tuum clock false vadit - emenda tuum clockum - tuum clok vadit false -

horologium -horologium - horologio - horologio - horologio ${ }^{41}$

The sermonist is here building extreme lexical cohesion through repetition: within three paragraphs and 61 lines in Horner, reference to "timepiece « is made seventeen times, twelve of those times in Latin (with the expected Latin case endings as required by Latin morphosyntax) and five times in English. All five English forms of clok/clock appear in the middle paragraph, between two mostly Latin paragraphs. In this middle paragraph, where the saturation of English appears, the word clok is embedded twice into English syntax (bi clok most be set; set pi clok perafter) and three times the word clok/clock is embedded in Latin, showing insertional switching. Within Latin syntax, this English word behaves like a Latin word, with assimilation to Latin morphosyntax. While the form clockum, showing the Latin inflectional suffix -um, is rare in the macaronic sermon corpus, it follows the proposed syntactic constraints where the transitive verb emenda "change « assigns the accusative case to its direct object tuum clockum "your clock «. ${ }^{42}$ The twelve English words that appear in example (10) are the only English words within the 61 lines that focus on the theme of time.

39 Horner, Macaronic Sermon Collection, 244-245.

40 Halliday and Hasan, Cohesion in English. See also Johnson, Grammar of Good Friday.

41 Horner, Macaronic Sermon Collection, 35-37, lines 168-228.

42 For the syntactic principles governing the switching in most cases, see Halmari and Regetz, Syntactic aspects. 
So, what does the switching from Latin horologium to English clok do here? First, example (10) would nullify any hypotheses according to which the preacher resorts to English words when he does not know their Latin equivalents. Second, this type of switching introduces a break in the long, potentially monotonous, sequence with multiple mentions of one lexical item in Latin: horologium. Introducing its English equivalent brings a colorful (and perhaps welcome) change into the theme of salvation. Mainly, however, by introducing lexical variation in the form of the English clok/clock, the preacher continues to build semantic coherence to this topic, without tiring the listener by too much repetition of the same word - clever avoidance of »horror equi«.

Repetition, but not too much repetition, seems to be one of the leading persuasive principles of the preacher of Bodley 649. Repetition, of course, builds coherence, and coherence builds up the persuasive power of the message. Lexical variation, the use of synonyms or translation equivalents (horologium vs. clok/clock), allows for the building of semantic coherence while simultaneously helping the speaker to avoid sounding repetitive. Example (11) from Sermo 3, "Great is faith", is another illustration of cohesion-building, now achieved via the sermonist's repetition of the verb climb. Because the use of climb involves a switch from Latin into English, its use provides simultaneous variation from the surrounding text:

(11) Non mouerent dubia de fide, climbe non alcius quam eorum sensus possit attingere, set credere docentur [...]. Set iam, quod dolendum est, [...] animalia terrestria han clymbe vp on hy. [...] Sicut quidam dicunt laici and a clymbin al to hye.

"They should not raise doubts about faith, climb no higher than their senses can grasp, but believe what they are taught [...]. But now, sad to say, [...] the earthly animals have climbed up on high. [...] Just as some lay people speak out and have climbed all too high.«43

In example (11), the preacher builds up the English "momentum « around the word climb (and around the sins of pride and selfishness), starting from just a one-word insertion (climbe "climb «), then moving to a verb phrase (han clymbe vp on hy "have climbed up on high«), and finally ending up with an entire English clause (and a clymbin al to hye "and have climbed all too high"). In this way, the sermonist of Bodley 649 plays with coherence by breaking it when he switches from Latin to English, but builds it back by lexical repetition within the code-switched segments.

As Wenzel points out (see examples in [5d] above), alliteration is another rhetorical device that often bundles with language switching. ${ }^{44}$ Through repetition of the same initial phonetic element in collocating words, the sermonist is building up audible cohesion. Examples (1214) illustrate this:

43 Horner, Macaronic Sermon Collection, 78-79.

44 Wenzel, Macaronic Sermons, 88-90. See also Halmari and Regetz, Language switching and alliteration. 
(12) Pulcra folia, verbum Dei, incipiunt cadere, lati rami, articuli, fadoun fast, et tota arbor Christiane fidei arescit et sterilescit.

"The beautiful leaves, the word of God, begin to fall, the wide branches, the articles, fade fast, and the whole tree of Christian faith dries up and becomes sterile. $\aleph^{45}$

(13) In prosperitate et aduersitate, in weel and woo serua [f. 8] arma ista super te.

»In prosperity and adversity, in weal and woe, keep these arms on you. $\aleph^{46}$

(14) Memento quod quantum-cumque sis gay and gret, morieris: [...] nescis quo vadis, ad gloriam uel ad penam, weel uel woo.

"Remember that no matter how gay and great you may be, you will die:

[...]; you do not know where you will go, to glory or to pain, to weal or to woe. « ${ }^{47}$

In example (12) above, it is alliteration that coincides with code-switching. However, in examples (13-14), it is not only alliteration but also structural parallelism that coincides with the switch to English. In (14) the coordinated Latin phrase ad gloriam uel ad penam adds to the overall structural parallelism realized in the fully English gay and gret and also in weel uel woo, where two parallel English words are conjoined by the Latin uel. This is an important point because code-switching does not always need to be involved with the use of other rhetorical, cohesion-building devices. If it were, the sermonist would be showing mere mechanical application of his skills; what he is doing is adding to the rhetorical (and persuasive) value of his sermon in a creative, non-mechanical way. Structural parallelism can be seen as a realization of grammatical cohesion, here achieved by the means of conjunction - another cohesion-building device listed by Halliday and Hasan. ${ }^{48}$

The next example, from Sermo 2, shows a different incident of structural parallelism that adds to grammatical cohesion while language switching (a potential threat to cohesion) is present. Example (15) shows the consecutive use of three English adjectives - nedful »necessary«, spedeful »advantageous«, and mydful »meritorious«:

(15) [...] prima turris est misericordia tui et ista turris est tibi nedful; secunda turris est misericordia pauperis et ista turris est tibi spedeful; tercia turris est misericordia tui hostis et hec tibi est mydful.

"[...] the first tower is mercy towards yourself, and this tower is necessary to you; the second tower is mercy towards the poor, and this tower is advantageous to you; the third tower is mercy towards your enemy, and this is meritorious for you. $\aleph^{49}$ 
All three adjectives appear in the same clause-final position, within three parallel structures: NP1 + copula est $» i$ is $+\mathrm{NP} 1+$ conjunction et "and + NP1 + copula est tibi/tibi est is for you "/»for you is " + ADJ. According to the Functional Sentence Perspective, ${ }^{50}$ the sentence-final position typically provides new (not given) information. The three sentence-final adjectives underscore this new information in the focal position of the sentence, the end. From the point of view of the sermonist, the adjectives capture the essence of the metaphor of the three towers. Note that all three adjectives end in the same derivational suffix -ful; this adds lexical cohesion to structural cohesion.

These additional rhetorical strategies that coincide with and support the switches into English are strategies that add to the effectiveness and cohesion of the message ${ }^{51}$ and are found in monolingual texts as well.

I hope to have established that code-switching is persuasive because it breaks the monotony of just one sermon language. While code-switching ostensibly breaks the cohesion by introducing a different language, it simultaneously builds this cohesion back through (1) repetition (paraphrasing the Latin message in English), (2) lexical cohesion (by recycling the Latin lexical material through English words); (3) enhanced lexical cohesion via alliteration (both within the inserted English elements and across English and Latin); and (4) grammatical cohesion through structural parallelism (often via conjunction or via identical, parallel structures). These elements coincide with code-switching, overlapping yet not completely correlating, as total overlap would be too mechanical in nature.

\section{The Content of the English Switches}

I have looked at the bundling of coherence-building features that add to the persuasive nature of the macaronic sermons in Bodley 649. Now I wish to end this article with a brief discussion about the semantic content of the switched English elements.

Examples (16-18) give a hint of what kind of semantic material often seems to coincide with the inserted English elements:

(16) Si fueris a lecchour sequens delectaciones corporis, colis falsam deam, pe ladi of lust; eius mammona in tua anima est fetens hircus luxurie.

"If you are a lecher following the delights of the body, you cherish a false goddess, the lady of lust; her idol in your soul is the stinking goat of luxury. « ${ }^{52}$

(17) Ista execrata vasa, pes poysunmongeres, demon iecit inter nos.

»These cursed jars, these poisonmongers, the devil throws among us. ${ }^{53}$

(18) Si aliquis sub tua cura cadat vltra tabulam in mare, into Lollardri, luxuriam, uel aliud mortale, facias debitum tuum and pi besines: retrahere eum sursum.

50 See, e.g., Firbas, Concept of communicative dynamism; Firbas, Functional Sentence Perspective.

51 Cf. Johnson, Grammar of Good Friday, xvi.

52 Horner, Macaronic Sermon Collection, 224-225. For a discussion of this example from the point of view of its alliterative qualities coinciding with switching to English, see Halmari and Regetz, Language switching and alliteration, 320.

53 Horner, Macaronic Sermon Collection, 278-279. 
"If anyone under your care falls beyond the board into the sea, into Lollardy, lust, or other mortal sin, do your duty and your business: drag him up. $\aleph^{54}$

In examples (16-18), reference to lechers, ladies of lust, and poisonmongers coincide with English insertions. The Latin that embeds these English nominals describes them in no flattering terms. Of course, the word poisonmongers of example (17) refers to the Lollards, despised by the Bodley 649 sermon writer, and example (18) makes an unambiguous reference to Lollardy, comparable to »lust, or other mortal sin«. Further examples include pes rioturs "these rioters" and ze sinful men "you sinful men.$^{55}$

While it is not within the purview of this study to address the content of all the English switches in Bodley 649 (the number of these switches runs into thousands), a quick look at switches in Sermo 9 and Sermo 10 shows that many carry negative content:

(19) a. schame and vilony "shame and villainy"

b. synne and wickednes "sin and wickedness"

c. wo and wrechetnes "woe and wretchedness"

d. ful nedi, and nacut "very needy, and naked"

e. qui sunt gredi et cupidi "who are greedy and avaricious $\aleph^{56}$

English elements in (19a)-(19e) show conjoined nouns; in addition, alliteration is added in wo and wrechetnes "woe and wretchedness" (19c) and ful nedi, and nacut "very needy, and naked" (19d). When referring to sinful thoughts and desires, the preacher may resort to the vernacular (of wickud thoztes "of wicked thoughts", foule lustis »foul desires «), ${ }^{57}$ and the reference to the devil may also trigger a switch to English (with pe gobline »by the evil spirit«). ${ }^{58}$ In example (20), the switch to English does not take place for the word pomum "apple« but for the words worme ete:

(20) istud pomum est worme ete intus

»this apple [...] it is wormeaten within « ${ }^{59}$

Without a quantitative study of the contents of all the English elements within all the sermons, these examples provide no basis for generalization; however, these examples may show that a shocking, disgusting, or reproachable content may be found in the English insertions. Down-to-earth concepts lend themselves to vernacular expression:

54 Horner, Macaronic Sermon Collection, 278-279.

55 Horner, Macaronic Sermon Collection, 266-267, 244-245.

56 Horner, Macaronic Sermon Collection, 236-237, 264-265, 244-247.

57 Horner, Macaronic Sermon Collection, 266-267.

58 Horner, Macaronic Sermon Collection, 240-241.

59 Horner, Macaronic Sermon Collection, 244-245. 
(21) Omnem welth ponunt in a wombe ioy, so pe bali repleatur non cupiunt aliam felicitatem.

"They put all their wealth into the stomach's pleasure, as long as the belly is full they do not desire any other happiness. ${ }^{60}$

Wealth and wombe in (21) provide coherence by added alliteration, and the preacher's message is probably more condemnatory because the names of the body parts (wombe, bali) are expressed in the vernacular.

The final example, (22), consists of two sentences where grammatical coherence is built partially through structural parallelism: a list of noun phrases that reference allegorical animals representing vices. In both sentences, these noun phrases are introduced by parallel forms (Hic ambulant $X$; Hic intus serpit $Y$ ):

(22) Hic ambulant rapaces leones superbie, vorax vrsus gule, pe gredi lupus auaricie, pe wile fox decepcionis et falsitatis. Hic intus serpit pe eddur inuidie, ardens serpens luxurie, et alia venenosa animalia omnium viciorum.

"Here prowl the rapacious lions of pride, the voracious bear of gluttony, the greedy wolf of avarice, the wily fox of deception and falsehood. Here crawl the adder of envy, the burning serpent of lust, and the other poisonous animals of all the vices. ${ }^{61}$

The noun phrases - rapaces leones superbie; vorax vrsus gule; pe gredi lupus auaricie; pe wile fox decepcionis et falsitatis; be eddur inuidie, ardens serpens luxurie; alia venenosa animalia omnium viciorum - attract attention because of their right-dislocated position. Because the sermon author has placed these phrases in the sentence-final position, his intention must have been to underscore these allegorical animals (lion, bear, wolf, fox, adder/serpent, other poisonous animals) that stand for pride, gluttony, avarice, deception and falsehood, envy, lust, and "all the vices." However, the sermon author resorts also to other rhetorical devices to flag these noun phrases as important for his message. I argue that it is not a coincidence that the author uses also the vernacular to draw attention to the negative traits, repulsive habits, and even deadly sins that the animals stand for. Three of the seven noun phrases are introduced by a switch to English: pe gredi lupus auaricie; pe wile fox decepcionis et falsitatis; and $p e$ eddur inuidie. The repeated English determiner pe adds to coherence while, simultaneously, introducing a different language - a potential problem for cohesion. In summary, the parallel list of allegorical animals draws attention not only through structural parallelism but also through the use of some initial vernacular for three of them. The wolf, the fox, and the adder are not only the incarnations of avarice, deception and falsehood, and envy; they are also flagged by the switch to English.

60 Horner, Macaronic Sermon Collection, 242-243.

61 Horner, Macaronic Sermon Collection, 238-239. 


\section{In sum}

Within the macaronic texture of Oxford, MS Bodley 649, English elements seem to serve as an effective rhetorical device that the sermons' author uses to persuade. By switching from Latin to English, he breaks away from the monotony of one language, and this perhaps helps his bilingual audience to follow, pay attention, and stay awake. I have argued that switching often coincides with other rhetorical strategies that build coherence within the text: lexical repetition, alliteration, and structural parallelism. In addition, the content of the sermons is down-to-earth and tangible, often associated with sin, filth, and foulness. For the audience, the switches to English may also be reminders about salvation as a matter of their daily lives, conducted in English - not just an academic topic discussed in Latin with sterile words and abstractions.

At first, one might think that by switching languages within one speech situation the preacher is likely to break the cohesion (and consequently the coherence) of his message. However, with his skillful use of English and his abundant employment of cohesive devices, he ends up building back cohesion - while also keeping his audience awake. Thus, the preacher's use of code-switching and his bundling of the cohesive devices contribute to the highly persuasive nature of these macaronic sermons. Even though code-switching itself is not necessarily persuasive, both the structure and the content of the switches in Bodley 649 add to the effects of this already hortative genre.

\section{Acknowledgments}

I am grateful to Timothy Regetz for his help with the data analysis of Oxford, Bodley 649 and to Robert Adams for the discussions during the preparation of this article. I also want to thank David Denison and the audience of the University of Manchester Linguistics and English Language seminar, where I presented an early version of this paper on October 25, 2016, as well as the participants of the Vienna conference »Understanding Multilingual Sermons of the Middle Ages: Forms, Methodologies, and Challenges«, at the Institute for Medieval Research, Austrian Academy of Sciences, 15th-17th May 2018, for the helpful discussion. 


\section{References}

Archan, Sabine, Functional and Structural Aspects of Code-Switching in Middle English and Early Modern English Texts. Unpublished MA dissertation (University of Vienna, 2000).

Benson, C. David, Another fine manuscript mess: Authors, editors, and readers of Piers Plowman, in: Derek Pearsall (ed.), New Directions in Later Medieval Manuscript Studies: Essays from the 1998 Harvard Conference (Woodbridge, 2000) 15-28.

Burrow, John A. and Hoyt N. Duggan (eds.), Medieval Alliterative Poetry: Essays in Honour of Thorlac Turville-Petre (Dublin, 2010).

Carroll, Ruth, Matti Peikola, Hanna Salmi, Mari-Liisa Varila, Janne Skaffari and Risto Hiltunen, Pragmatics on the page: Visual text in late medieval English books, European Journal of English Studies 17/1 (2013) 54-71.

Classen, Albrecht (ed.), Multilingualism in the Middle Ages and Early Modern Age: Communication and Miscommunication in the Premodern World (Berlin, 2016).

Ferguson, Charles A., Diglossia, Word 15/2 (1959) 325-340.

Firbas, Jan, Functional Sentence Perspective in Written and Spoken Communication (Cambridge, 1992).

Firbas, Jan, On the concept of communicative dynamism in the theory of functional sentence perspective, in: Sborník Prací Filosofické Fakulty Brněnské University, Studia Minora Facultatis Philosophicae Universitatis Brunensis A 19 (1971) 135-144.

Haines, Roy M., »Our Master Mariner, Our Sovereign Lord«: A Contemporary Preacher's View of King Henry V, Medieval Studies 38 (1976) 85-96.

Haines, Roy M., "Wilde Wittes and Wilfulness«: John Swetstock's attack on those »Poyswunmongeres, " the Lollards, in: G. J. Cuming and Derek Baker (eds.), Popular Belief and Practice: Papers Read at the Ninth Summer Meeting and the Tenth Winter Meeting of the Ecclesiastical History Society (Cambridge, 1972) 143-153.

Halliday, Michael A. K. and Ruqaiya Hasan, Cohesion in English (London, 1976).

Halmari, Helena, Visual presentation of Latin in Piers Plowman, Oxford, Bodleian Library, MS Rawlinson Poetry 38 (R): What is the pattern? (forthcoming).

Halmari, Helena and Timothy Regetz, Language switching and alliteration in Oxford, MS Bodley 649, in: Albrecht Classen (ed.), Multilingualism in the Middle Ages and Early Modern Age: Communication and Miscommunication in the Premodern World (Berlin, 2016) 313-328.

Halmari, Helena and Timothy Regetz, Syntactic aspects of code-switching in Oxford, MS Bodley 649, in: Herbert Schendl and Laura Wright (eds.), Code-Switching in Early English (Berlin, 2011) 115-153.

Horner, Patrick J. (ed. and trans.), A Macaronic Sermon Collection from Late Medieval England: Oxford, MS Bodley 649 (Toronto, 2006).

Jefferson, Judith A. and Ad Putter (eds.), Multilingualism in Medieval Britain (c. 1066-1520): Sources and Analysis, Medieval Texts and Cultures of Northern Europe 15 (Turnhout, [2013]).

Johnson, Holly, The Grammar of Good Friday: Macaronic Sermons of Late Medieval England (Turnhout, 2012).

Keller, Mareike, Code-switched adjectives in macaronic sermons, in: Elise Louviot and Catherine Delesse (eds.), Studies in Language Variation and Change 2: Shifts and Turns in the History of English (Newcastle upon Tyne, 2017) 197-216. 
Machan, Tim William, The visual pragmatics of code-switching in late Middle English literature, in: Herbert Schendl and Laura Wright (eds.), Code-Switching in Early English (Berlin, 2011) 303-333.

Matras, Yaron, Language Contact (Cambridge, 2009).

McClure, Erica and Malcolm McClure, Macro- and micro-sociolinguistic dimensions of code-switching in Vingard, in: Monica Heller (ed.), Codeswitching: Anthropological and Sociolinguistic Perspectives (Berlin, 1988) 25-51.

Millward, C. M. and Mary Hayes, A Biography of the English Language (third edition), (Boston, 2012).

Owst, Gerald R., Literature and Pulpit in Medieval England: A Neglected Chapter in the History of English Letters and of the English People (second revised edition), (Oxford, 1961).

Owst, Gerald R., Preaching in Medieval England: An Introduction to Sermon Manuscripts of the Period c. 1350-1450 (New York, 1965).

Pahta, Päivi, Janne Skaffari and Laura Wright (eds.), Multilingual Practices in Language History: English and Beyond (Boston, 2018).

Piers Plowman Electronic Archive. Retrieved on 10 December 2020: piers.chass.ncsu.edu/.

Rothwell, William, English and French in England after 1362, English Studies 82/6 (2001) 539-559.

Schendl, Herbert, Code-switching in late medieval macaronic sermons, in: Judith A. Jefferson and Ad Putter (eds.), Multilingualism in Medieval Britain (c. 1066-1520): Sources and Analysis, Medieval Texts and Cultures of Northern Europe 15 (Turnhout, [2013]) 153-169.

Schendl, Herbert, Syntactic constraints on code-switching in medieval texts, in: Irma Taavitsainen, Terttu Nevalainen, Päivi Pahta and Matti Rissanen (eds.), Placing Middle English in Context (Berlin, 2000) 67-86.

Schendl, Herbert and Laura Wright (eds.), Code-Switching in Early English (Berlin, 2011).

Schendl, Herbert and Laura Wright, Code-switching in early English: Historical background and methodological and theoretical issues, in: Herbert Schendl and Laura Wright (eds.), Code-Switching in Early English (Berlin, 2011) 15-45.

Schreier, Daniel and Marianne Hundt (eds.), English as a Contact Language (Cambridge, 2013).

Schultz, Sarah and Mareike Keller, Code-switching ubique est: Language identification and part-of-speech tagging for historical mixed text, in: Nils Reiter, Beatrice Alex and Kalliopi A. Zervanou (eds.), Proceedings of the 10th SIGHUM Workshop on Language for Cultural Heritage, Social Sciences, and Humanities ( $\mathrm{LaTeCH}$ ) (Berlin, 2016) 43-51. Retrieved on 27 January 2021: www.aclweb.org/anthology/W16-2105/.

Taavitsainen, Irma, Terttu Nevalainen, Päivi Pahta and Matti Rissanen (eds.), Placing Middle English in Context (Berlin, 2000).

Thomason, Sara Grey and Terrence Kaufman, Language Contact, Creolization, and Genetic Linguistics (Berkeley, 1988).

Trotter, David A. (ed.), Multilingualism in Later Medieval Britain (Cambridge, 200o).

Turville-Petre, Thorlac, The Alliterative Revival (Cambridge, 1977).

Wenzel, Siegfried, Macaronic Sermons: Bilingualism and Preaching in Late-Medieval England (Ann Arbor, 1994).

\section{List of tables}

Table 1: The distribution of Latin and English words in the sample passage from Sermo 5 $(n=155)$.

Table 2: Examples of switched syntactic forms and their functions. 